ОСОБЛИВОСТІ РОЗВИТКУ

СВІТОВОГО ГОСПОДАРСТВА ТА МЕВ

УДК 330.341 .1

\title{
COMPETITIVENESS OF THE UKRAINIAN ECONOMY: THE INNOVATION DIMENSION
}

\section{КОНКУРЕНТОЗДАТНІСТЬ ЕКОНОМІКИ УКРАЇНИ: ІННОВАЦИЙНА СФЕРА}

\section{КОНКУРЕНТОСПОСОБНОСТЬ ЕКОНОМИКИ УКРАИНЫ: ИННОВАЦИОННАЯ СФЕРА}

\section{Filipenko A.S.}

Dr. of Econ. Sciences, Prof., Institute of International Relations, Kyiv National Taras Shevchenko University. E-mail: anton_filipenko@ukr.net

\section{Rylach N.M.}

PhD (Econ.), Senior Research Fellow of the Institute of International relations of Kyiv Taras Shevchenko National UniversityInstitute of International Relations Taras Shevchenko National University of Kyiv. E-mail: nrylach28@gmail.com

\section{Kramarenko A.V.}

Postgraduate student at the Department of world economy and international economic relations in the Institute of International Relations, Kyiv National Taras Shevchenko University. E-mail: akrana@i.ua

\section{Філіпенко А.С.}

Професор, Доктор економічних наук Інституту міжнародних відносин Київського національного університету імені Тараса Шевченка. E-mail: anton_filipenko@ukr.net

\section{Рилач Н.М.}

Кандидат економічних наук, старший науковий співробітник НДЧ Інституту міжнародних відносин Київського національного університету імені Тараса Шевченка. E-mail: nrylach28@gmail.com

\section{Крамаренко А.В.}

Аспірант кафедри світового господарства і міжнародних економічних відносин Інституту міжнародних відносин Київського національного університету імені Тараса Шевченка. E-mail: akrana@i.ua

\section{Филипенко А.C.}

Профессор, доктор экономических наук Института международных отношений Киевского национального университета имени Тараса Шевченко. E-mail: anton_filipenko@ukr.net

\section{Рылач Н.М.}

Кандидат экономических наук, старший научный сотрудник НДЧ Института международных отношений Киевского национального университета имени Тараса Шевченка. E-mail: nrylach28@gmail.com

\section{Крамаренко А.В.}

Аспирант кафедры мирового хозяйства и международных экономических отношений Института международных отношений Киевского национального университета имени Тараса Шевченко. Е-таil: akrana@i.ua 
Abstract. The purpose of research is to analyze the level and innovation potential of Ukraine's economics. In the current world economy, the innovation dimension is becoming essential for boosting the country's competitiveness. Development of competitive high-tech industries and manufacturing facilities; a strong national innovation system; availability of effective internal and institutional mechanisms, as well as external tools for involving countries into 'the knowledge society': all these factors contribute most to the nation's economic success in the global environment.

Keywords: competitiveness, innovation, Association Agreement between Ukraine and the EU, Global Competitiveness Index, national innovation system, digitalisation of the economy

Анотація. Метою дослідження $\epsilon$ аналіз рівня $і$ інноваційного потенціалу економіки Украӥни. У сучасній світовій економічі інноваційний аспект стає важливим для підвищення конкурентоспроможності країни, розвитку конкурентоспроможних високотехнологічних галузей та виробничих потужностей. До факторів, щчо сприяють економічному успіху краӥни в глобальному середовищі відносяться: потужна національна інноваційна система, наявність ефективних внутрішніх та інституційних механізмів, а також зовнішніх інструментів для залучення країн до «суспільства знань».

Ключові слова: конкурентоспроможність, інновачії, Угода про асоџіаџію між Украйною та ЄС, Глобальний індекс конкурентоспроможності, національна інноваційна система, цифровізація економіки.

Аннотация. Целью данного исследования является анализ уровня и инновационного потенциала Украины. В современной мировой экономике инновационный аспект становится важным для повышения конкурентоспособности страны, развития конкурентоспособных высокотехнологичных отраслей $u$ производственных мощңностей. $K$ факторам, способствующим экономическому успеху страны в глобальной среде относятся: мощная национальная инновачионная система, наличие эффективных внутренних $u$ институциональных механизмов, а также внешних инструментов для привлечения стран к «обществу знаний»

Ключевые слова: конкурентоспособность, инноващии, Соглашение об ассоџииции между Украиной и ЕС, Индекс глобальной конкурентоспособности, национальная инновационная система, иифровизаџия экономики.

Introduction. In the context of globalisation, the competitiveness of the national economy may be fostered by successful transition from the developmental model, based on the exploitation of resources, to the innovation model, where the priorities lie in the development of high-tech industries, excellent human capital, and the latest management methods. However, the efficiency of transition to the innovation-driven model depends on the effectiveness of involving available human capital in the creation of innovation, the readiness of society, country, government, employers, and communities to accept these systemic innovations based on the need to update and retrain professional skills and competences, and continuously apply them under the conditions of dynamic technological changes.

The purpose of research is to analyse the competitiveness of the Ukrainian economy in its current state; to identify the place of the innovation factor in the system of its main determinants; and to justify the choice of a strategy, methods and means for a more comprehensive inclusion of national innovation potential as a driver for boosting international competitiveness of leading industries and regions of Ukraine.

Recent literature review. Scholarly studies of economic competitiveness were initiated and advanced by J. Hart, E. Heckscher, P. Krugman, S. Linder, B. Ohlin, M. Porter, D. Sax, L. Summers, and others. The issue has also been reflected in the works of scholars from the post-soviet states: O. Bilous, R. Fatkhutdinov, B. Inozemtsev, D. Lukyanenko, S. Menshykov, I. Spyrydonov, S. Sokolenko, , T. Tsygankova, Y. Yakovets, Y. Zhalilo, and others.

The development of the Ukrainian national competitiveness strategy in the context of globalisation has been studied by O. Amosha, V. Aleksandrova, Y. Bazhal, O. Bolkhovitinova, V. L. Fedulova, Gejets, A. Danylenko, V. Semynozhenko, V. Sidenko, L. Shynkaruk. Currently, such 
issues as the innovation dimension of the Ukrainian economy competitiveness, the search of effective institutional forms, as well as the elaboration of internal and external mechanisms for incorporating the innovation component into the national competitiveness development strategy, call for a more comprehensive analysis.

Main research result. Today, innovation determines both the level of national economic development and the growth rate of a country's competitiveness. However, the current state of the Ukrainian economy is characterised by insufficient funding and poor investment strategy in the high-tech sector and predominance of the third and fourth technological paradigms in the industry structure. The investment into the fifth wave industries amounts to mere $4.5 \%$, while almost $75 \%$ of all investments are channelled into the low-efficiency industries of the third technological wave. The proper conditions for the country's innovation development - which, according to the world practice, is the key contributing factor to the growth of a country's competitiveness - have not been created yet. Current development of the world economy is characterised by increased intellectualisation of labour and sophistication of the means of production, which allows to create new competitive high quality goods and services with high added value. Knowledge and its bearers - the intellectual capital of a country - are the crucial elements in the production of such goods and services. Hence, the knowledge economy is the only viable strategic direction for the development of both society and the country. The biggest challenge for Ukraine today is to transform its obsolete resource-based economy into the modern knowledge-based one. The development and support of national high-tech industries is a part of the long-term process of building a competitive innovation economy - the economy based on commercialisation of knowledge. [Стратегія розвитку високотехнологічних галузей до 2025 року; 1]

Cross-country comparisons based on global indices provide an effective tool for identifying the current state of the Ukrainian national competitiveness in the context of the growing role of the knowledge economy and the impact of the innovation component on the economy competitiveness. The World Economic Forum held annually in Davos, Switzerland is a major event aimed at, among other objectives, highlighting the competitiveness of individual countries.

The Global Competitiveness Index is comprised of more than 100 variables grouped in twelve control values ('Institutions', 'Infrastructure', 'Macroeconomic environment', 'Health and primary education', 'Higher education and training', 'Goods market efficiency', 'Labour market efficiency', 'Financial market development', 'Technological readiness', 'Market size', 'Business sophistication', and 'Innovation potential') that, in turn, are divided into three main groups of subindexes: 'Basic requirements', 'Efficiency enhancers', and 'Innovation and sophistication factors'.

In 2017, Ukraine ranks $81^{\text {st }}$ among 137 countries of the world, improving its position by four points. Yet, in 2017 Index, Ukraine loses nine points in the innovation component, while in the infrastructure component the country goes down by three points and in higher education and training it slides by two points.

Table 1.

The position of Ukraine and some other countries, according to the Global Competitiveness Index

\begin{tabular}{|l|c|c|c|c|c|c|}
\hline $\begin{array}{l}\text { The position of } \\
\text { Ukraine and some } \\
\text { other countries, } \\
\text { according to the } \\
\text { Global } \\
\begin{array}{l}\text { Competitiveness } \\
\text { Index }\end{array}\end{array}$ & $\begin{array}{c}\mathbf{2 0 1 2 -} \\
\mathbf{2 0 1 3} \text { (out } \\
\text { of 144) }\end{array}$ & $\begin{array}{c}\mathbf{2 0 1 3 -} \\
\mathbf{2 0 1 4} \text { (out }\end{array}$ & $\begin{array}{c}\mathbf{2 0 1 4 -} \\
\mathbf{2 0 1 5} \text { (out } \\
\text { of 144) }\end{array}$ & $\begin{array}{c}\mathbf{2 0 1 5 -} \\
\mathbf{2 0 1 6} \text { (out } \\
\text { of 140) }\end{array}$ & $\begin{array}{c}\mathbf{2 0 1 6 -} \\
\mathbf{2 0 1 7} \text { (out } \\
\text { of 138) }\end{array}$ & $\begin{array}{c}\mathbf{2 0 1 8} \text { (out } \\
\text { of 137) }\end{array}$ \\
\hline Ukraine & & & & & & \\
\hline Georgia & 73 & 84 & 76 & 79 & 85 & 81 \\
\hline Turkey & 47 & 72 & 69 & 66 & 59 & 67 \\
\hline Russia & 67 & 44 & 45 & 51 & 55 & 53 \\
\hline Poland & 41 & 42 & 53 & 45 & 43 & 38 \\
\hline
\end{tabular}


Source: Economic discussion club; Position of Ukraine in rating of the worldwide cities by global competitiveness index; [2].

Table 2.

The Global Competitiveness Index of Ukraine

\begin{tabular}{|c|c|c|c|c|c|}
\hline \multirow{3}{*}{$\begin{array}{l}\text { The Global Competitiveness } \\
\text { Index of Ukraine }\end{array}$} & $\begin{array}{l}2015- \\
2016 \text { (out } \\
\text { of } 140 \text { ) }\end{array}$ & $\begin{array}{l}2016- \\
2017 \text { (out } \\
\text { of } 138 \text { ) }\end{array}$ & $2017-2$ & (out of 137) & \multirow{3}{*}{$\begin{array}{l}\text { Trend (10 } \\
\text { latest } \\
\text { studies) }\end{array}$} \\
\hline & \multicolumn{3}{|c|}{ Rating position } & Score & \\
\hline & 79 & 85 & 81 & 4,1 & \\
\hline Basic requirements & 101 & 102 & 96 & 4,2 & \\
\hline Institutions & 130 & 129 & 118 & 3,2 & \\
\hline Infrastructure & 69 & 75 & 78 & 3,9 & \\
\hline Macroeconomic environment & 134 & 128 & 121 & 3,5 & \\
\hline Health and primary education & 45 & 54 & 53 & 6,0 & \\
\hline Efficiency enhancers & 65 & 74 & 70 & 4,1 & \\
\hline Higher education and training & 34 & 33 & 35 & 5,1 & \\
\hline Goods market efficiency & 106 & 108 & 101 & 4,1 & \\
\hline Labour market efficiency & 56 & 73 & 86 & 4,0 & \\
\hline Financial market development & 121 & 130 & 120 & 3,1 & \\
\hline Technological readiness & 86 & 85 & 81 & 3,8 & \\
\hline Market size & 45 & 47 & 47 & 4,5 & \\
\hline $\begin{array}{l}\text { Innovation and sophistication } \\
\text { factors }\end{array}$ & 72 & 73 & 77 & 3,5 & \\
\hline Business sophistication & 91 & 98 & 90 & 3,7 & \\
\hline Innovations & 54 & 52 & 61 & 3,4 & \\
\hline
\end{tabular}

Source: Economic discussion club; Position of Ukraine in rating of the worldwide cities by global competitiveness index; [2].

In 2018, according to the Global Competitiveness Report published by the World Economic Forum, Ukraine gets 57.03 points out of 100, which corresponds to the 83rd place among 1401 countries of the world. From 2007 to 2018, the Competitiveness Index of Ukraine averages to 12.60 points, reaching its maximal value of 57.03 points in 2018 and hitting the record low rate of 3.90 points in 2011. [Trading economics; 3]

In 2018, the World Economic Forum introduced a new methodology to it's Global Competitiveness Report intended to include the concept of the Fourth Industrial Revolution into the definition of competitiveness by complementing the assessment of competitiveness with such components as 'Enabling environment', 'Human capital', 'Markets', and 'Innovation ecosystem' comprised of the same values. In 2018, Ukraine was ranked as follows:

1. Enabling environment:

- institutions - rank 110 , value - 46,3 points;

- infrastructure - rank 57, value - 70,1 points;

- use of ICT - rank 77, value - 51 points;

- macroeconomic stability - rank 131, value - 56 points.

2. Human capital:

- $\quad$ health - rank 94, value - 72 points; 
- professional skills - rank 46, value - 69 points.

3. Markets:

- goods market - rank 73, value - 55.3 points;

- labour market - rank 66, value - 59 points;

- financial system - rank 117 , value - 49 points;

- market size - rank 47, value - 63 points.

4. Innovation ecosystem:

- business dynamics - rank 86 , value - 58 points;

- innovation skills - rank 58, value - 39 points. [4]

Thus, innovations, if they reach appropriate markets and help generate commercially viable incomes, become a powerful force that drives economic efficiency. All the world economies, regardless of their stage of development, could respond to the challenges of the Fourth Industrial Revolution by exploiting the opportunities of innovation. The Global Competitiveness Index suggests a wider approach based on three principles: firstly, the county's ability to innovate depends on the quality and size of its innovation ecosystem; secondly, it is considered that innovation is a process where ideas can turn into successful products; and thirdly, innovations occur everywhere, not only in laboratories, and their results take many shapes, from production of goods and services to the creation of new business models for companies and organisations.

The Global Innovation Index is a global study undertaken by the INSEAD School of Business, Cornell University, and the World Intellectual Property Organization. The purpose of this study is to analyse the level of integration of innovations in institutions, education, infrastructure, and businesses, and to present the findings in a corresponding ranking. This year, 126 countries have been included in the ranking. Ukraine demonstrates relatively high innovation rate in human capital (education) and research (43rd rank), and business sophistication (46th rank). At the same time, institutions and infrastructure still demonstrate the lowest results (107th and 89th place accordingly)[Happy Monday talks; 5]. In 2017, Ukraine ranked 50th in Global Innovation Index. By index components, Ukraine held the following positions: institutions - 107th, human capital and research $-43 \mathrm{rd}$, infrastructure - 89th, market sophistication - 89th, business sophistication - 49th, knowledge and technology output -27 th, creative output $-45^{\text {th }}$ [Global innovation index; 6]. This leads to a conclusion that the country's absolute values remain almost unchanged, although the country's closest competitors are demonstrating much higher innovation potential. According to the Index, the causes of Ukraine's economic problems may be explained by the political instability and the weakness of financial markets and state institutions. Low student mobility rates, small spending on research and very limited investment into knowledge-efficient industries are drawing attention and raising concerns. Ukraine's strengths include high rate of tertiary enrolment, ease of getting a credit and ease of starting a business. [ Management of future consulting group; 7]

According to the 2017 A. T. Kearney Global Services Location Index, Ukraine ranks 23rd in the global competitiveness ranking of outsourcing in the IT industry. [Indre Vareikite; 9] The assessment is made on the basis of factors that create the enabling environment and enhance the competitiveness of the IT industry. These factors include financial attractiveness where Ukraine scores 3.23, people skills and availability (score 1.14), and business environment (score 0.93).

Since the declaration of Ukraine's Independence, its research and innovation industry has experienced various cuts, especially in terms of total expenditure on R\&D as a share of GDP, and in terms of the number of institutions and research staff. The current situation is characterised by 
limited government funding for the industry and the economic structure that does not rely on research and development. However, the competitiveness of a country directly depends on its paying attention to the innovation development, stimulating the development of national innovation system and efficiently utilising the tools of regional cooperation. For Ukraine, a major priority of international scientific cooperation is the country's integration to the European Research Area (ERA). This integration is facilitated by multilateral and bilateral cooperation agreements with the EU and its member states. [ Indre Vareikite; 9]

In 2002, Ukraine and the EU signed an agreement on cooperation in the areas of scientific research and technology advancement. There are several programmes of the EU aimed at the cooperation of the European Union with Ukraine for research and innovation: FP7 — the Seventh Framework Programme for Research and Innovation, Horizon 2020 - Framework Programme for Research and Innovation, Erasmus Mundus, Tempus, Jean Monnet programmes under the Lifelong Learning Programme, INSC, and INOGATE. The two latter programmes are funded through the European Neighbourhood Instrument (ENI). Cross-border cooperation programmes are funded by ENI, and the programme for Central Europe is a part of the European programme for cross-regional cooperation.

Ukrainian national priorities in the field of science and technology are stipulated in its legal documents. Presently, the national priorities are defined in the Law of Ukraine 'On priority directions of development of science and technology' (2001) that defines the following directions as important for science and technology development until 2020:

- fundamental research of the most important problems of development of scientific, technical, social and economic, social and political, human potential for ensuring competitiveness of Ukraine in the world and sustainable development of society and the state;

- information and communication technologies;

- power and energy efficiency;

- rational environmental management;

- life sciences, new technologies for the treatment and prevention of the most widespread diseases;

- new substances and materials.

These directions are specified in the law of Ukraine 'On the Priority Directions of Innovation Activity in Ukraine' (2011) [Project of digital agenda of Ukraine 2020; 10]

The integration into the European Research Area (ERA) is one of the main priorities of international cooperation of Ukraine in the field of R\&D. It is facilitated by multilateral and bilateral cooperation with the EU and its member states. Overall, Ukraine, the EU member states, and associate members of Horizon 2020 have signed 25 active intergovernmental treaties for cooperation in the field of R\&D. On 20 March 2015, Ukraine joined Horizon 2020 programme as an associated member and this marked an important step in the Ukraine-EU cooperation in the area of research, technology, and innovation. Moreover, in 2016 Ukraine signed a participation treaty in the EuroAtom programme. Such course of events demonstrates the political will of Ukraine for the future EU membership. The inclusion into the Horizon 2020 programme became the first instance of associate participation of Ukraine in the EU programmes. The success rate (successful applications or participation in applications) of Ukrainian researches in the Seventh European Framework Programme for Research and Technical Development is $19.5 \%$. Within FP7 programme, Ukraine has signed 155 grant contracts, 215 Ukrainian participants are involved in the implementation of projects that received $30.9 \mathrm{ml}$ euro of European financing. Ukraine ranks 7 th among the countries of the third world participating in he Seventh European Framework Programme for Research and Technical Development (FP7), both for the number of participants 
and budget share. It has demonstrated good performance (considering the number of signed grant contracts) in the fields of environment protection (16), transport (15), INCO international cooperation (15), Marie Skłodowska-Curie actions (15), and nanotechnologies (13 contracts).

At the same time, while researching the issue of innovation dimension of the country's competitiveness, we believe it is important to emphasise the need for the 'digitalisation' of the Ukrainian economy. Digitalisation is known to contribute to efficiency enhancement, economic growth, creation of new workplaces, and potential improvement of the quality of living of Ukrainians. The digital economy operates within the same categories as the traditional economy, i.e. capital, resources, and people. The driving force of the digital economy is human capital that comprises knowledge, talents, skills, abilities, experience, and people's intelligence. [Project of digital agenda of Ukraine 2020; 10]

The rapid spread of digital technologies makes our digital skills prime to many other skills. The impact becomes possible with the integration of ideas, initiatives and programmes that deal with digitalisation, in national and regional strategies and programmes of development. The key purpose of this principle is to achieve the digital transformation of existing fields of economy, activities, and new properties and features. The digitalisation of Ukraine must be focused on the international, European, and regional cooperation with the aim of Ukraine's integration into the EU. It is the digitalisation that might eventually help Ukraine to integrate into the European and global systems in the area of information and communication technologies.

Presently, the key trends of digitalisation are as follows:

- Data is becoming the main source of competitiveness. It can be accessed through the Internet or other networks. An increasingly sizable share of the world data is open.

- The development of the Internet of things, i.e. the network comprised of the interconnected physical objects (or goods) or devices with built-in sensors and software that enables connecting physical objects with the computer systems and networks, including the Internet. [Project of digital agenda of Ukraine 2020; 10]

'Digitalisation' and digital transformation. Digital technology has become a foundation for the creation of products, values, properties, and, consequently, contribute to the competitive advantage in most of the markets. Such transformation leads to the emergence of new, unique systems and processes that comprise their new value (for example, Uber, Airbnb, digital banking, etc). The majority of common activities tend to undergo a digital transformation. Transformations in the industry occur consistently with the 'Industry 4.0' concept and with the advent of cyberfactories, cyber-systems, and cyber-machines. Digitalisation and the possibilities of outsourcing of the development of new products and business services, production and quick prototyping allows small companies and project teams create new products and quickly bring them on the market at the same pace as that of big companies. As a result, the 'innovation centres' have shifted from big companies to the small ones (e.g. start-ups).

Distribution of the 'sharing economy' business model. The business models of the 'sharing economy', based on the digital technologies, have significantly influenced the world economy. Globalisation of major markets (vendors and consumers) and replacement of manual processes by software-controlled systems allows local companies to do their business in a more cost-effective, convenient, and efficient way on regional and global markets. Cloud technology is also part of this trend.

Virtualisation of the physical infrastructure if IT-systems and transition to the service models. Using cloud technologies and software-defined architecture, virtualisation greatly reduces the initial capital costs for the deployment of required digital infrastructure. This technology allows renting computational capabilities and services, depending on the needs of a particular business process. A user can quickly access the service and securely rent out the technological platforms for the time required. [Project of digital agenda of Ukraine 2020; 10] An important strategic direction to enhance the competitiveness of Ukrainian economy consists in making sure that Ukraine joins the global Industry 4.0 process - a renewed concept of the 'smart factory', synonymous to the 
Fourth Industrial Revolution and the advent of cyber systems. 'Industry' means a new stage of digitalisation where technologies such as Big Data analytics, predictive analytics, machine learning, machine-to-machine communication, artificial intelligence, new generation of robots, and others, become prominent. Due to gradual cheapening, these technologies become accessible, i.e. they start being used more frequently by industries and businesses, which eventually transforms the existing business models or simply creates the new ones. This increases the competitiveness of industries, stimulates the domestic market, helps maintain and increase the positions in the sectors with high value added on the national and, in some cases, on the global levels. Yet, this is only an opportunity to gain the appropriate knowledge, expert examination, and consultation in this new field. Apart from information and knowledge work, Ukrainian political elite, state institutions and businesses must develop integrated initiatives aimed at effective implementation of the 'Industry 4.0' potential in Ukraine. Today, the Ukrainian IT industry is involved into the execution of international integrated projects through the following business practices [Project of digital agenda of Ukraine 2020; 10]:

- 'digital transformation', integrated digital transformation of business, i.e. the use of innovation technologies for achieving the effect of strategic change and business processes of a company, resulting in the drastic enhancement of the business efficiency and achieving the competitive benefits by transforming the structure, including such practices as IoT, Big Data, augmented intelligence, etc;

- 'digitalisation' of the customer interaction system, i.e. formation of adaptive operational models based on the study of consumer behaviour, according to the data collected;

- Big Data and advanced analytics, i.e. new concepts of collection, processing and interpretation of analytical data, using IoT and artificial intelligence;

- R\&D, i.e. development of principally new algorithms that require research and development of complex technological concepts;

- advice on software development and management practices of software development projects;

- IT-infrastructure management;

- software development, implementation, and maintenance;

- customised software development;

- software quality assurance, development of automated and manual testing scripts in order to ensure that the tested software meets its objectives.

The document (p. 53-55) defines the basic strategic technologies for the public sector of Ukraine: the Digital Workplace, Multichannel Delivery of Information and Citizens Engagement, Open Data, Electronic ID, Widespread Analytics, Smart Machines and Tools, the Internet of Things, Digital Public Platform, Software -Defined Architectures, and Blockchain. In 2018, Ukraine is mainly a consumer of foreign high-tech devices and products. Digital technologies, especially at the periphery with other high-tech industries, have a colossal developmental potential and represent a source of the future research and applied discoveries and advancements. Such digital trends as the Internet of Things, Big Data analytics, and Industry 4.0 will have provided a great space for researchers, innovators, and developers for at least the forthcoming 15 to 20 years. The implementation of Ukrainian science for the new digital devices, creation of new technologies and systems can significantly impact the economy, domestic market, and the establishment of the modern innovation infrastructure as an important factor of enhancing the international competitiveness of the Ukrainian economy. The integration of Ukrainian science in the European 
Research Area will contribute to this, since it provides an opportunity for the development of the most promising trends, participation in interdisciplinary cooperation projects that focus on prospective ideas, technologies, and innovations. At the same time, developments in this area need to follow a common strategy involving thee components: industry/businesses, research, and the digital sector. [Report. 'Horizon 2020'; 12]

Key steps in this field should include: analysis of research potential and existing innovations; setting up the Technology Transfer Centres; participation in the EU core research programmes in the areas of nano-electronics, organic electronics and photonics; development of the Technology Roadmap for each industry; competition for financing and integration of priority study areas; transparent mechanism of engaging research staff to projects; governmental support and funding for the best researchers and research centres in national and European digital infrastructure projects. The participation of Ukrainian R\&D and ICT companies in the EU long-term research projects that have a potential of becoming a source of innovation and discoveries has strategic importance for the country. Such EU project include Future Emerging Technologies (FET), Future Networks, Future Internet Research and Experimentation (FIRE), and the Brain Research initiative.

The Digital Agenda of Europe in the field of research and ICT innovation [Digital agenda for Europe; 11] defines three directions for joint efforts for the member EU states and other interested countries that engage in building the European Research and Innovation Area:

1. The development of interoperable e-infrastructures for research and innovation clusters in the key areas, the use of cloud computing for government and science, for instance, the development of the GEANT education network and the distributed computing, collection, saving, and data processing system of the European Grid Infrastructure (EGI).

2. Access to data and publications, acquired by government funds, creation of Technology Roadmaps for public-private partnerships (PPP), commercialisation of research products for industry and society.

3. The development of open and interoperable digital solutions for launch and development of innovation ecosystems in industrial sectors, development and implementation of open standards and platforms for new products and services.

In order to catch up with these trends, Ukraine needs to ensure the development of its own research digital infrastructure for the priority directions where high-tech growth is expected. The funding mechanism of fundamental research should combine both budget support and consistent demand for high-tech products from the industry, small and medium-sized business, and the companies of ICT sphere. Institutional and financial consolidation of fundamental research can also be attained in the framework of implementation of international projects and development of infrastructure.

The latest EU initiatives in the field of innovation and ICT include the creation of European Research Area for innovation and society: Open Innovation, Open Science, Open World; creation of the European Cloud Initiative that provides the creation of the European Open Science Cloud and the European Data Infrastructure that shall provide digital services for research, industry, businesses, and governments of the EU countries.

Therefore, key steps for the development of digital research infrastructure of Ukraine shall include the following:

1. Inclusion of the Ukrainian National Grid (UNG) project into the European Grid Infrastructure (EGI) and pilot introduction of the corresponding EGI's cloud infrastructure in the UNG resource centres. The project includes coordination of management system, standards and services with the development programme of the Open Science Cloud and data infrastructure financed by the EU. There is a pressing need to update the UNG infrastructure for connection with the European Data Infrastructure by 2020 when it is planned to run the supercomputers with the capacity of 1-2 exaflops. 
2. Scaling up a pilot model to the national cloud initiative, using all UNG clusters and involving digital libraries, archives, medical, ecology, energy and other data systems, including private DCs on the pay-to-use basis. To provide its interoperability with main einfrastructures of the European Open Science Cloud and the European Data Infrastructure: the United Cloud of EGI, OpenAIRE, EUDAT, Indigo Data Cloud, Helix Nebula - The Science Cloud, PRACE.

3. Creation of digital learning platforms for undergraduate and postgraduate training on the basis of the UNG and EGI potential for research and product innovation, and also for the training of data processing root experts for each discipline. [12] The development and support of high-tech areas represent an inseparable part of innovation dimension of the country's competitiveness. Ukraine's competitive advantages include skilled and experienced human capital (31st place, The Human Capital Report 2015), land resources and $33 \%$ of the world's supply of highly fertile black soils (chernozem); geographical location; natural resource base). Still, an effective exploitation of these resources is only possible by transforming the traditional resource-based economy into the innovation knowledge-driven one. That is why it is increasingly relevant to focus on enhancing the knowledge potential of the country's priority industries, using information and communication technologies and intensive implementation of innovations.

In addition to the innovation components that affect the national competitiveness, the efficiency of the Ukrainian companies depends on investment in the updates of equipment, their ability to meet customers' requirements and provide services at attractive prices compared to competition. Economic growth is frequently connected with the achievements in the field of efficiency based on investments and increased effectiveness. But, as noted in the paper entitles 'The summary of innovation activity values in Ukraine', 'Ukraine is not fully integrated into the global value chain, and the studies have indicated that it stays outside of the customer-oriented (e.g., clothes manufacturing) and production-oriented networks, including spare parts and finished products.' [Report. 'Horizon 2020'; 12]

Major high-tech areas for development in Ukraine include the development of informationtelecommunication technologies; the implementation of ICT in AIC, energy industry, transportation, manufacturing industry; high-tech machinery; production of new materials; pharmacy and bioengineering. However, high-tech areas account only for 6\% of GDP and 5.5\% of export; GDP knowledge intensity (costs of research implementation as a GDP share in Ukraine) is currently at $0.77 \%$. [Strategy on high-tech industry development till 2025; 1]

Globally, after a fall in the period of 2000 to 2007, the share of high-tech products in the world exports had stabilised at the level of $10 \%$. This is characteristic for such developed economies as USA, Germany, and Japan. In Ukraine, the share of high-tech exports amounts to 3\% (in 2017, the share high-tech products amounted to only 5.5\% of total exports). [Ukrinform; 13] Primary sector goods, materials and intermediate goods with a relatively low technology value dominate the Ukrainian export and reach almost 70\%. The AIC production amounts to $41 \%$ (USD17.7 bn), metallurgical production - 23.4\% (USD10.1 bn), machinery production $-11.7 \%$ (USD5 bn), mineral products, etc - $9.1 \%$ (USD3.9 bn).

The share of high-tech export of Ukraine is less than 5.5\%. On the other hand, the secondary sector (manufacturing and building industries) prevails in industrialised and developed economies [14] and by this indicator, Ukraine falls behind most of the developed countries. Aerospace industry dominates the Ukrainian high-tech export (the average for the period analysed is 36.2\%), electronics and telecommunications ranks second (17.7\%), non-electronic machinery and armament holds the third place (17.6\%). The member states of the Eurasian Economic Union are biggest importers of the Ukrainian high-tech products (over 43\% of high-tech export). The Ukrainian share of high-tech exports is lower than the global average and it should be possible to increase the share of high-tech export by attracting investment to projects involving the production of finished hightech products; strengthening the protection of intellectual propriety rights to foster patent-protected 
products; promoting research and business cooperation in order to stimulate the process of innovation. [White book; 15]

An effective transition to the knowledge economy and increased country competitiveness can only be effected by making the changes in the following components:

Economic agenda. Funding of research and product development, introduction of innovation technologies, and upgrade of the industry infrastructure. Currently, the main source of innovation funding (75-85\% of total financing) consists of the companies' own funds. Under crisis conditions, driven by the rise of costs on imported spare parts and raw materials and the need for meeting social obligations, companies are forced to reduce funding not only for innovation activities, but also for research and development (R\&D). Recently, due to economic fall and increased spending for defence of the country, state funding of $R \& D$ in Ukraine has declined. At the same time, lack of funding for research can lead to irreversible processes of migration and retraining of personnel, collapse in infrastructure and technical base, etc. In 2016, the share of spending on R\&D amounted to 0.48 of GDP of Ukraine. [State statistic agenda; 16]

According to the World Bank estimates, Ukraine ranks 93rd in the economy sub-index, affected by the country's imperfect regulatory and tariff policy.

Innovation and technology infrastructure. Overall tear-and-wear of production facilities and machinery (reaching over $80-90 \%$ in some industries) has led to low competitiveness of the country's domestic economy. This results in low efficiency, excessive energy and resourceintensive production and consequently, higher cost and lower added value per product unit. Ukraine ranks 93rd among 127 countries by the level of protection of Intellectual Property Rights. The situation with intellectual property rights represents an important incentive for technology transfer and attracting investment in the high-tech branches;

Education and human capital. Modernization of the system of higher and professional vocational education and improved access to education are fundamentally important element of human capital development;

ICT infrastructure. The obstructive approach of the government to information and communication technologies (ICT) in the period of 2000-2014 has undermined the industry and turned Ukraine into one of the least technologically developed countries in Europe. According to the study, Ukraine is still gradually falling behind the developed countries in the advancement of information society.

The Association Agreement between Ukraine and the EU provides the necessary tools for the successful transformation of innovation in Ukraine. Systemic implementation of the European agenda gives the following opportunities in the areas of research, technology, and innovation [Report from 17 november 2017 year 'Ukraine- EU'; 17]:

- Taking part in the development of EU research and development strategy and agreeing the corresponding national strategy with its principles.

- Introduction of the European principles of independent evaluation of research and its quality assurance.

- Defining priorities in the innovation industries development Ukrainian within ERA in the framework of the Smart Specialization Strategy.

- Alignment of the state-funded targeted research and technology programmes with the programmes of the EU member states, and the creation of International Research Networks.

- Access to up-to-date research and digital EU infrastructure and the creation of national hubs.

- Access to the single marketplace of researchers.

- Access to open data and knowledge in the European Digital Single Market. 
- Ensuring the transition from commercialisation of research findings to their joint implementation and exploitation in common innovation ecosystems.

In 2005, Ukraine signed the agreement with the EU on the country's participation in the EU Horizon 2020 programme - Framework Programme for Research and Innovation (2014-2020) [Agreement between Ukraine-EU 'Horizon 2020' 18] - another milestone in the realisation of Association Agreement between Ukraine and the EU. The programme's aim is to achieve the creation of Single European Research Area and Innovation Union. This agreement gives Ukraine the right to participate in its formal structures, including programme committees and the ERA groups, in education and innovation communities of European Innovation Scoreboard, and in the activities of the Joint Research Centre, under the same conditions which apply to the legal entities of the EU member states. The participation in the Horizon 2020 enabled the implementation of a framework agreement on the joint research between the National Academy of Science of Ukraine and JRC, to take part in the development of the Smart Specialization Strategy, and cover those areas where Ukraine can be competitive on the European market. The status of associated country in this programme also gives Ukraine an opportunity to participate in all-European coordination of policies in the area of research and innovation, and to use the tools for knowledge transfer in this field. In 2016, in the framework of one of the Horizon 2020 tools, namely Policy Support Facility (PSF), the European Commission conducted an independent audit of the Ukrainian national policy in the field of research and innovation.

Conclusions. The innovation dimension of the competitiveness of Ukrainian economy calls for transformations in institutional environment with regard to doing business, creation of favourable innovation climate, revitalization of research and development, effective exploitation of up-to-date information and communication technologies, digitalisation of economy, implementation of the Ukraine-EU Association Agreement and Horizon 2020 to ensure that the country caches up with the EU countries by the national innovation system value. [Innovation Ukraine; 19].

\section{References}

1. СТРАТЕГІЯ РОЗВИТКУ ВИСОКОТЕХНОЛОГІЧНИХ ГАЛУЗЕЙ ДО 2025 РОКУ, http://www.me.gov.ua/Documents/Detail?lang=uk-UA\&id=c3081991-45fb-47df-abc659822e854a99\&title=ProektstrategiiRozvitkuVisokotekhnologichnikhGaluzeiDo2025-Roku.

2. Економічний дискусійний клуб. 'Позиція України в рейтингу країн світу за індексом глобальної конкурентоспроможності 2017-2018' [Position of Ukraine in , http://edclub.com.ua/analityka/pozyciya-ukrayiny-v-reytyngu-krayin-svitu-za-indeksomglobalnoyi-konkurentospromozhnosti-2

3. Trading economics. Summery 2018, <https://tradingeconomics.com/ukraine/competitivenessindex.>

4. World economic forum, <http://www3.weforum.org/docs/GCR2018/05FullReport/TheGlobalCompetitivenessReport201 8.pdf. p. 577>

5. Нарpy Monday Talks. Україна піднялася на 7 позицій у Глобальному індексі інновацій, [ Ukraine has raised up to 7 positions in Global innovation index], https://talks.happymonday.com.ua/ukraina-u-globalnomu-indeksi-innovacij/

6. Global innovation index, https://www.globalinnovationindex.org/gii-2018-report\# 
7. Management of future consulting group, Україна в міжнародних економічних рейтингах, [ Ukraine in international economic rating ], http://m-cg.com.ua/ua/ukraine-world-index-2016$2017 /$

8. 2017 A.T. Kearney Global Services Location Index, https://www.atkearney.com/documents/20152/793366/The+Widening+Impact+of+Automation. pdf/42b06cf4-e5f9-d8ec-a30c-a82dd26d4953

9. 5-ТЕ ЗАСіДАННЯ ПЛАТФОРМИ ГРОМАДЯНСЬКОГО СУСПІЛЬСТВА УКРАЇНА-СС м.Київ, 15 Листопада 2017 року ПРОГРЕС У ВПРОВАДЖЕННІ ЄВРОІНТЕГРАЦІЙНИХ РЕФОРМ У ГАЛУЗІ НАУКИ ТА ТЕХНІКИ В УКРАЇНІ Підготовлено: Індре Варейкіте (Indrè Vareikyte்), член СЕСК , [ $5^{\text {th }}$ Later of the Platform of the combating Ukraine-EU, Kyiv, the $15^{\text {th }}$ of November 2017, process in implementing eurointegration reforms in science and technology sector in Ukraine, prepared by Indre Vareikyte ].

10. Проект Цифрова адженда України - 2020 («Цифровий порядок денний» - 2020) Концептуальні засади (версія 1.0) Першочергові сфери, ініціативи, проекти «цифровізації» України до 2020 року, [ Project digital agenda of Ukraine 2020 ( Digital agenda) Conceptual background (version 1.0) Priority areas, initiatives, projects for 'digitization' of Ukraine until 2020 ].

11. The EU explained: Digital agenda for Europe. Luxembourg: Publications Office of the European Union, 2014 https://eige.europa.eu/resources/digital_agenda_en.pdf

12. Заключний звіт незалежного європейського аудиту національної системи досліджень та інновацій України Інструмент політичної підтримки програми «Горизонт 2020» Короткий зміст та рекомендації щодо покращення секторальної політики, [ Final Report of the Independent European Audit of the National Research and Innovation System of Ukraine 'Horizon 2020' Policy Support Instrument Summary and Recommendations for Sectoral Policy Improvement ].

13. https://www.ukrinform.ua/rubric-economy/2348018-ukrainskij-eksport-skladaetsa-z-sirovinina-70-minekonomiki.html

14. Укрінформ. Український експорт складається з сировини на 70\% - Мінекономіки, [ Ukrinform, Ukrainian export consist of raw material on $70 \%$ ], http://forumkyiv.org/uk/analytics/ukrayinskij-eksport:-krok-vpered-chi-big-na-misci

15. Біла книга. Як реалізувати експортний потенціал України за умов глобалізації, [ White book. How to realize export potential of Ukraine in globalization situation ], http://platformamsb.org/wp-content/uploads/2016/06/White_book_export_UKR_2016.pdf

16. Державна служба статистики України, Наукова та інноваційна діяльність України, [ State statistics office of Ukraine. Scientific and innovative activities of Ukraine ], http://www.ukrstat.gov.ua/druk/publicat/kat_u/2018/zb/09/zb_nauka_2017.pdf

17. ІМПЛЕМЕНТАЦІЯ ЄВРОІНТЕГРАЦІЙНИХ РЕФОРМ У СФЕРІ НАУКИ Й ТЕХНОЛОГІЙ Доповідь Платформи громадянського суспільства Україна-СС ;Київ, 15 листопада 2017 року, [ Implementation of European integration reforms in the science and technology. Report of the Ukraine-EU civil society platform. Kyiv, November 15, 2017 ], https://www.civic-synergy.org.ua/wp-content/uploads/2018/04/Science_all.pdf

18. Законодавство України, Угода між Україною і СС про участь України у програмі ЄС «Горизонт 2020», [ Legislation of Ukraine, Agreement between Ukraine and EU in the frame of program 'Horizon 2020'], http://zakon2.rada.gov.ua/laws/show/984_018 
19. Інноваційна Україна 2020: національна доповідь / за заг. ред.В.М. Гейця та ін.; НАН України. - К., 2015. - 336 с.: За загальною редакцією: В.М. Гейця, А.І. Даниленка, Е.М. Лібанової, А.А. Гриценка, О.В. Макарової, М.О. Кизима, І.Ю. Сгорова, І.В. Одотюка, [ Innovational Ukraine 2020 : national report edited by Geyc V. M. ]. 